\title{
Poglądy Kasjodora na temat sprawowania urzędów państwowych na podstawie XI i XII księgi Variae
}

Europejska tradycja administracyjna i podległe jej urzędy sięgają swoimi korzeniami dziejów państw starożytnego wschodu, państw greckich i Imperium Romanum. Powstające w okresie antycznym struktury państwowe kształtowały ośrodki władzy, poszerzając zakres spraw, którymi zarządzały. Proces ten prowadził do angażowania coraz większej liczby współpracowników zatrudnionych $\mathrm{w}$ działanie aparatu państwowego ${ }^{2}$. W okresie cesarstwa rzymskiego najważniejszym ośrodkiem władzy była kancelaria cesarska, w ramach której funkcjonowały różne komórki określane jako biura (officia). Oprócz kancelarii wykształciło się również szereg innych urzędów, a jednym z najważniejszych było stanowisko prefekta pretorium. Po upadku cesarstwa zachodniorzymskiego w większości zachowano struktury cesarskiej administracji państwowej. Jednym z najwybitniejszych przedstawicieli pełniących urząd prefekta pretorium w okresie późnej starożytności chrześcijańskiej był pochodzący z kręgów rzymskiej arystokracji Kasjodor Senator ${ }^{3}$. Świadectwem jego wieloletniej działalności na dworze królewskim jest ważne dla historiografii i kultury europejskiej dzieło Variae 4 . Materiałem źródłowym powyższego opracowania jest wyżej

${ }^{1}$ Michał Kieling - dr hab., prof. UAM, pracownik w Zakładzie Teologii Historycznej Wydziału Teologicznego UAM w Poznaniu, e-mail: kielingm@amu.edu.pl, ORCID: 0000-00032635-7246.

2 Zob. G. Górski, Historia administracji, Kraków 2011, s. 1-39.

${ }^{3}$ M. Kieling, Rola Pisma Świętego i „artes liberales” $w$ ksztaltowaniu nauk teologicznych i świeckich wedtug Kasjodora, Poznań 2011, s. 13-14.

${ }^{4}$ Cassiodorus Senator, Variae, MGH AA XII, T. Mommsen, ed. Berolini 1894; Variarum libri XI, A. J. Fridh, ed. CCL, Turnholti 1973; Kasjodor Senator, Variae (I-XII), thum. A. Kołtunow- 
wspomniane dzieło ze szczególnym uwzględnieniem księgi XI i XII, w których znajdują się pisma urzędowe samego Kasjodora z czasu sprawowania przez niego urzędu prefekta pretorium. Jeśli chodzi o status quaestionis podejmowanego zagadnienia, to należy stwierdzić, że w dotychczasowych opracowaniach poświęconych Kasjodorowi nie podjęto tematyki jego poglądów na temat pełnienia urzędów państwowych na podstawie Variae ${ }^{5}$. Niniejszy artykuł stawia sobie za cel przedstawianie w oparciu o zachowane źródła literackie poglądów oraz zasad, które powinny być zachowywane przy piastowaniu urzędów państwowych wyższych i niższych szczebli.

\section{Kasjodor jako prefekt pretorium}

Magnus Aurelius Cassiodorus Senator urodził się w Kalabrii w miejscowości o nazwie Scyllaceum (dziś: Squillace) około 485 roku i zmarł około 580 roku$^{6}$. Pochodził on z rodziny o dużych tradycjach rzymskich, cechującej się zaangażowaniem politycznym na dworze królewskim? ${ }^{7}$. Jego przodkowie, w tym dziadek i ojciec, piastowali wysokie stanowiska państwowe ${ }^{8}$. Kasjodor był ceniony przez Teoderyka Wielkiego (493-526), który dostrzegał jego zdolności pisarskie i administracyjne9. W 503 roku Kasjodor rozpoczął karierę urzędniczą u boku

ska, Przedmowa, Księgi I-V.IX, R. Sawa - Księgi VI-VIII.X-XII, rewizja przekładu i opracowanie M. Ożóg, H. Pietras, Synody i Kolekcje Praw, t. XI (ŹMT 79), Kraków 2017.

${ }^{5}$ W opracowaniach poświęconych Kasjodorowi zwraca się przede wszystkim uwagę na jego biografię związaną z pełnieniem wysokich urzędów państwowych - zob.: M. D. Cappuyns, Cassiodore, DHGE XI, Paris 1949, s. 1349-1408; J. J. O’Donnell, Cassiodorus, Berkeley-Los Angeles-London 1979; Ch. Kakridi, Cassiodors Variae. Literatur und Politik im ostgotischen Italien, Leipzig-München 2005.

${ }^{6}$ Rok urodzenia Kasjodora można określić na podstawie cursus honorum. Datacja rozciąga się między 485 rokiem lub nawet wcześniej a 490 rokiem. Podobnie jest w przypadku daty śmierci Kasjodora. Według swojej wzmianki w De orthographia (PL 70, 1241) dożył on 93 roku życia, co pozwala ustalić datę śmierci na około 580 rok - zob.: A. J. Fridh, Cassiodor, TRE VII, Berlin-New York 1981, kol. 657; W. Bürsgens, Einleitung, w: Cassiodorus, Institutiones divinarum et saecularium litterarum, ed. W. Bürsgens (FC 39/1-2), Freiburg im Breisgau 2003, s. 7.

${ }^{7}$ Nazwisko to potwierdzają najlepsze rękopisy dzieł Kasjodora w tym Variae i De anima. Nomen gentile brzmiało Cassiodorus - zob. Cassiodorus, Senati urbis Romae Theodericus Rex., Variae 1, 4, 9 (ŹMT 79, s. 12). Nosił je zarówno dziadek, jak również ojciec Kasjodora. Kasjodor sam oznaczył wszystkie znajdujące się w księgach XI i XII Variae pisma jako senator - zob.: W. Bürsgens, dz. cyt., s. 7; J. J. O’Donnell, dz. cyt., s. 267-268; Cassiodorus, Anecdoton Holderi. Ein Beitrag zur Geschichte Roms in ostgotischer Zeit, ed. H. Usener, Hildesheim-New York 1969 (Bonn 1877, s. 3n), s. 44; M. D. Cappuyns, dz. cyt., s. 1350.

${ }^{8}$ Zob. Cassiodorus, Cassiodoro V.I. atque Patricio Theodericus Rex., Variae 1, 3-4 (ŹMT 79, s. 9).

9 Zob.: M. Ożóg, ,Inter duas potestates”. Polityka religijna Teoderyka Wielkiego, Kraków 2012, s. 16-18, 97-99; M. Ożóg, Rozporzadzenia prawne Teoderyka Wielkiego w kwestiach religij- 
ojca jako consiliarius, w czasie kiedy sprawował on w latach 503-506 urząd prefekta pretorium na dworze gockim w Rawennie ${ }^{10}$. Następnie pełnił on urząd o nazwie quaestor sacri palatii ${ }^{11}$, a w 514 roku zostal mianowany konsulem (consul ordinarius). W latach 523-527 powierzono mu urząd kanclerza (magister officiorum), a po śmierci Teoderyka Wielkiego pełnił on ten urząd jeszcze w pierwszym roku rządów jego córki Amalasunty, która była regentką małoletniego Atalaryka (526-534) ${ }^{12}$. Dnia 1 września 533 roku Kasjodor otrzymał urząd prefekta pretorium ${ }^{13}$. Z pisma władcy możemy dowiedzieć się o uznaniu, jakim cieszył się Kalabryjczyk na dworze królewskim:

Gdyby życzliwość nasza odnalazła Cię przypadkiem dotąd ukrytego i nieuhonorowanego, naprawdę cieszylibyśmy się z takiego odkrycia. Mielibyśmy jednak wątpliwości, czy twoje czyny będą dobre, ponieważ w nowości jest więcej nadziei niż owocu. Tymczasem, ponieważ chlubisz się niezliczonymi awansami oraz wspaniałą opinią naszego pana i dziadka, nie przystoi poddawać sprawdzeniu człowieka, dla którego podziw trudno nam jest wyrazić. Ponadto patrząc na Ciebie, możemy pochwalić nadzwyczajne rządy tego władcy. Kiedy byłeś bardzo młody, przyjął Cię na stanowisko kwestora oraz szybko odkrył, że posiadasz wiedzę i jesteś obeznany w prawach. Byłeś niewątpliwie najwyższą chlubą tamtych czasów - dzięki ciągłej służbie zapewniałeś królowi spokój w jego wielkiej trosce o wszystko, ponieważ dzięki sile twojej wymowy niosłeś tak wielki ciężar królewskiej myśli. Uważał Cię za przyjemnego $\mathrm{w}$ oficjalnych przemowach, nieugiętego przy zaprowadzaniu sprawiedliwości, wolnego od pożądliwości. Nie sprzedałeś jego przywilejów po dokonaniu jakiejś obrzydliwej wyceny, aby bogactwo dobrej opinii przyniosło $\mathrm{Ci}$ zaszczytne stanowisko, ponieważ nigdy nie ulegałeś próbie przekupstwa ${ }^{14}$.

Atalaryk podkreśla cechy osobowości Kasjodora, pozwalające mu powierzyć ten zaszczytny urząd, do których zaliczyć można jego wiedzę, znajomość prawa, sprawiedliwość i nieprzekupność. Sprawowanie najwyższego urzędu w państwie w czasach niestabilnej sytuacji politycznej nie należało do łatwych zadań. Śmierć Amalasunty w 535 roku zapoczątkowała „pałacową rewolucję”, stając

nych w ,Variae” Kasjodora, w: Rzymianie i barbarzyńcy. Religia-polityka - kultura. Materiaty V kongresu mediewistów polskich, t. 6, Rzeszów 2019, s. 169-188.

${ }_{10}$ Zob. A. J. Fridh, dz. cyt., kol. 657.

${ }^{11}$ Cassiodorus, Formula magisteriae dignitatis, 6, 6, $5-7$ (ŹMT 79, s. 227); A. J. Fridh, dz. cyt., kol. 657; T. Mommsen, Ostgotische Studien: Historische Schriften 3, Berlin-Dublin-Zürich 1965, s. 390 .

${ }^{12}$ Zob. T. Skibiński, „Gothorum romanorumque consensus”. Jedność Gotów i Rzymian w działalności politycznej Amalasunty, „Vox Patrum” 36(2016), t. 66, s. 235, 249.

${ }_{13}$ Zob. Cassiodorus, Senatori PPO Athalaricus Rex., Variae 9, 24, 1 (ŹMT 79, s. 363).

${ }^{14}$ Cassiodorus, Paulino V.C. Consuli Athalaricus Rex., Variae IX, 24, 1-4 (ŹMT 79, s. 363-364). 
się okazją dla cesarza Justyniana I Wielkiego (527-565) do najazdu Bizancjum i rozpoczęcia wojen. Na początku lat pięćdziesiątych VI wieku Kasjodor wycofał się z życia publicznego, poświęcając się życiu ascetycznemu i nauce chrześcijańskiej w założonym przez niego klasztorze Vivarium ${ }^{15}$.

Urząd prefekta pretorium posiadał długą tradycję, która swoimi korzeniami sięgała panowania cesarza Oktawiana Augusta (27 rok przed Chrystusem 14 rok po Chrystusie). Początkowo prefekt odpowiadał za bezpieczeństwo cesarza i posiadał znaczenie militarne. $Z$ czasem prefekci otrzymywali coraz większe uprawnienia administracyjne i sądownicze ${ }^{16}$, a ich wpływ na cesarzy skutkował faktycznym zwierzchnictwem nad innymi urzędami ${ }^{17}$.

Zakres kompetencji tego urzędu określa jego formuła, która znajduje się $\mathrm{w}$ datowanym na 511 rok dokumencie. Autor przedstawia w nim genezę tego officium, którego protoplastą według niego był starotestamentalny Józef ${ }^{18}$. Patriarcha ten jako pierwszy poświęcił insygnia tej godności i wsiadł do publicznego powozu oraz został wyniesiony na wyżyny chwały, aby mógł przynieść ludziom to, czego nie mogła im dawać władza panującego ${ }^{19}$.

W opinii Kasjodora najważniejszym zadaniem prefekta była władza napominania:

Stawia on bowiem przed sądem bez wyjątku tych, którzy się oddalili. Nakłada surowe grzywny na błądzących, rozdziela przychody publiczne według własnego uznania, ma podobne uprawnienie do udzielania praw wolnego przejazdu środkami poczty publicznej, konfiskuje nieodebraną własność, karze przestępstwa sędziów prowincjonalnych, wydaje wyroki. Czyż jest coś, czego nie powierzono by temu, którego prawdziwą mową jest orzekanie? Można by niemalże powiedzieć, że ma on władzę stanowienia praw, ponieważ mocą swej powagi może kończyć procesy bez apelacji ${ }^{20}$.

$\mathrm{Z}$ urzędem tym związane były także przywileje, a jednym z nich było okazywanie czci przy wejściu do pałacu. Pod względem władzy żaden urząd nie był mu równy, ponieważ prefekt sądził jak przedstawiciel cesarza i żaden urzędnik

15 Zob. M. Kieling, dz. cyt., s. 40-59.

${ }^{16}$ Zob. Apparatus criticus (ŹMT 79, s. 221); I. Jakubowski, Stanowisko pretora w „Kodeksie Teodozjańskim” o „Nowelach Postteodozjańskich”, „Acta” UL 32(1978), s. 35-45; S. Ruciński, „Praefectus Urbi”. Strażnik porzadku publicznego w Rzymie w okresie wczesnego Cesarstwa, Poznań 2012.

17 Zob. G. Górski, dz. cyt., s. 32.

${ }_{18}$ Cassiodorus, Formula praefecturae praetorio, Variae VI, 3, 3, 1 (ŹMT 79, s. 221).

${ }^{19}$ Cassiodorus, Formula praefecturae praetorio, Variae VI, 3, 3, 2 (ŹMT 79, s. 221).

${ }^{20}$ Cassiodorus, Formula praefecturae praetorio, Variae VI, 3, 3, 3 (ŹMT 79, s. 221-222). 
nie określał granic jego jurysdykcji, z wyjątkiem magistra militium ${ }^{21}$. Formuła tego urzędu określa jego kompetencje i znaczenie dla funkcjonowania państwa:

Na swoim urzędzie zachowuje szczególne przywileje i wydaje rozkazy ludziom takiej rangi, iż nawet sędziowie prowincjonalni nie ośmielają się ich w żaden sposób lekceważyć. Personel jego biura jest powszechnie szanowany, skuteczny, wyszkolony i silnego umysłu. Urzędnicy wykonują polecenia bez żadnej zwłoki. Tym, którzy wypełnili służbę w jego biurze, nadaje godność trybunów i notariuszy, czyniąc w ten sposób swoich urzędników równymi tym, którzy wraz z dostojnikami dworskimi towarzyszą naszemu pojawieniu się ${ }^{22}$.

Sprawowanie tego wysokiego urzędu miało przynosić korzyść i chwałę władcy oraz rzeczpospolitej, a prefekt pretorium miał cechować się silnym charakterem, rzetelnością oraz takimi cnotami, jak roztropność, męstwo, umiarkowanie i sprawiedliwość. Piastowanie tego officium nie mogło mieć nic wspólnego z tym, co niskie, nikczemne i występne ${ }^{23}$, ponieważ - jak czytamy w piśmie - „wypełnianie obowiązków prefekta pretorium jest pewnego rodzaju kapłaństwem”24.

\section{Posłuszeństwo władzy i zachowywanie prawa}

Jednym z priorytetów bogatej działalności Kasjodora była troska o zachowanie jedności gocko-rzymskiego państwa, które wymagało reformy w trudnych uwarunkowaniach religijnych, społecznych i kulturowych ${ }^{25}$. W swoich pismach urzędowych Kalabryjczyk mocno podkreślał posłuszeństwo oraz autorytet władzy. W piśmie skierowanym do Konstantyniana nasz autor pisze:

Majestat królewski stanowi zagrożenie dla niedbałych, ale i przynosi chlubę tym, którzy się do niego przyczyniają. Nagrodą w życiu jest służyć na oczach władcy, przed którym nie ukryje się wina ani dobro nie popadnie w zapomnienie ${ }^{26}$.

W piśmie do senatu rzymskiego datowanym na 534 rok, w którym nominat dziękuje za gratulacje przesłane od senatorów na jego ręce, Kalabryjczyk wyraża pogląd, że troska o nich skłania go ku sprawom publicznym i posłuszeństwu wobec władcy:

${ }^{21}$ Cassiodorus, Formula praefecturae praetorio, Variae VI, 3, 3, 4 (ŹMT 79, s. 222).

${ }^{22}$ Cassiodorus, Formula praefecturae praetorio, Variae VI, 3, 3, 5 (ŹMT 79, s. 222).

${ }^{23}$ Cassiodorus, Formula praefecturae praetorio, Variae VI, 3, 3, 8 (ŹMT 79, s. 222-223).

${ }^{24}$ Cassiodorus, Formula praefecturae praetorio, Variae VI, 3, 3, 8 (ŹMT 79, s. 223).

${ }_{25}$ Zob. T. Skibiński, dz. cyt., s. 235, 249.

${ }^{26}$ Cassiodorus, Constantiniano Vir Experientissimo Senator PPO., Variae XII, 18, 1 (ŹMT 79, s. 471). 
Zaraz po naszych władcach Wam najbardziej staram się polecać, wierzymy bowiem, że kochacie to, co jak wiemy, nakazują władcy państwa: po pierwsze, abyśmy uznawali za korzystne to, co uczciwe, aby naszym działaniom zawsze towarzyszyła sprawiedliwość, tego zaś, czego od wstrzemięźliwego władcy nie kupiliśmy, nikomu wstrętnie nie sprzedawali ${ }^{27}$.

Zatem uczciwość, sprawiedliwość i niesprzedajność stanowiły dla nowo mianowanego prefekta pretorium główne zasady postępowania. We wspomnianym powyżej piśmie autor podkreśla swoją lojalność wobec młodocianego władcy Atalaryka i jego matki Amalasunty, wskazując na ich zasługi dla państwa, jak również na ich cechy charakteru i umiejętności dyplomatyczne ${ }^{28}$.

W piśmie adresowanym do papieża Jana II (533-535) Kasjodor prosi następcę św. Piotra o jeszcze energiczniejszą modlitwę o zdrowie władców, o ich długie życie, o osłabienie wrogów rzeczpospolitej rzymskiej, o udzielenie spokojnych czasów, jak również o obfitość spichlerzy. Zwraca się także z prośbą o modlitwę w jego intencji, aby Bóg otworzył mu zmysł rozumności i udzielił daru rady ${ }^{29}$. Nadawca - co należy szczególnie zauważyć - staje z pokorą i szacunkiem wobec biskupa Rzymu, dając się poznać jako człowiek głębokiej religijności:

Pragnę jednak dobrze działać, nawet jeśli będę ganiony, bo trudniej błądzić owcy, która pragnie słyszeć głos pasterza, niełatwo stać się występną tej, którą nieustannie naciska napominający. $Z$ pewnością na dworze jestem sędzią, ale nie przestaję być waszym uczniem, bo wówczas przeprowadzimy to właściwie, kiedy jak najmniej odejdziemy od waszych zasad. Ponieważ jednak gorąco pragnę zarówno być przez was napominany radami, jak też wspierany modlitwami, należy już przypisać wam, jeśli znalazłoby się we mnie coś innego niż to, czego pożądano ${ }^{30}$.

W kolejnym piśmie skierowanym do różnych biskupów Kasjodor prosi pasterzy, aby gorliwie modlili się za niego i prosili Trójcę Świętą o łaskę widzenia wewnętrznego i umiejętność szerokiego spojrzenia na innych ${ }^{31}$ :

Cóż da sędziemu, że jest przejrzysty dla innych, jeśli siebie samemu sobie nieprzeniknionym? Oby obdarzył go godnym sumieniem Bóg, który zechciał powierzyć mi sprawy sądowe. Oby uczynił sędziego pewnym, aby nie potępiał żadnego błądzącego. Niech będzie obecny dla naszego dobra, aby zniknęły występki przy-

${ }^{27}$ Cassiodorus, Senatui Urbis Romae Senator PPO., Variae XI, 1, 1 (ŹMT 79, s. 407).

${ }^{28}$ Cassiodorus, Senatui Urbis Romae Senator PPO., Variae XI, 1-20 (ŹMT 79, s. 407-412).

${ }^{29}$ Cassiodorus, Iohanni papae Senator PPO., Variae XI, 2 (ŹMT 79, s. 413).

${ }^{30}$ Cassiodorus, Iohanni papae Senator PPO., Variae XI, 2 , 5 (ŹMT 79, s. 414).

${ }^{31}$ Cassiodorus, Diversis Episcopis Senator PPO., Variae XI, 3, 1 (ŹMT 79, s. 414). 
noszące nieszczęście. Niech udzieli swej miłości, aby litościwie usunąć grzeszne knowania ${ }^{32}$.

Nasz autor zwraca się z prośbą do pasterzy Kościoła, aby radzili mu przyjaźnie i pisze przy tym szczerze, że nie jest „przebiegłym zaprzańcem”, jednocześnie podkreślając, iż to, co powinien świadczyć, czyni w sposób nieprzymuszony ${ }^{33}$. W innym piśmie adresowanym do Ambrożego nadawca podkreśla, że wyżsi urzędnicy dworu powinni działać w interesie pożytku publicznego jak najsprawiedliwiej ${ }^{34}$. Znaczący urząd powinien oznaczać się dobrą opinią, odrzuceniem niedbalstwa oraz przekonaniem, że wszystko należy czynić z Bożą pomocą dla dobrego imienia i rzeczpospolitej ${ }^{35}$.

Ważnym kryterium w doborze współpracowników podejmujących służbę w urzędach państwowych była lojalność wobec przełożonych. W piśmie adresowanym do kanclerza Jana znajdujemy uwagę, że postępowanie podwładnego jest wyrazem poglądów jego zwierzchnika. Patrząc bowiem na podwładnego, można poznać sposób myślenia jego przełożonego. Dlatego każdy wybiera na swojego przedstawiciela takiego człowieka, za jakiego wszyscy uważają jego samego. Urzędnik dopuszczony do sekretów zwierzchnika - jak zauważa nasz autor - bądź to zdobi, bądź plami opinię przełożonego ${ }^{36}$. Kasjodor wskazuje również na transparentność działań urzędnika i zasadę posłuszeństwa:

Spójrz, gdzie zechciała postawić Cię starożytna tradycja: jesteś widoczny zewsząd, Ty, który działasz na oczach wszystkich. Skieruj zatem ku nam uszy i myśl, zapamiętaj sobie dokładnie wszystkie nasze rozkazy. Niech nasze słowa nie przelewają się przez Ciebie niby przez zniszczoną rurę, którą tak długo postrzega się jako pełną, jak długo mogą przez nią przepływać strumienie wody. Bądź raczej zbiornikiem, który strzeże tego, co usłyszał, który nie rozlewa tego, co zebrał, ponieważ nic to nie da, jeśli wchodzące słowa podobać się będą Twym uszom, nie zapadną jednak wszystkie głęboko $\mathrm{w}$ serce $^{37}$.

Kolejną ważną zasadą w pracy urzędnika jest kierowanie się sprawiedliwością w życiu zawodowym i prywatnym. W piśmie do przełożonych prowincji nadawca wskazuje na ducha służby i napomina przełożonych, aby sprawiedliwie przewodniczyli mieszkańcom prowincji:

${ }^{32}$ Cassiodorus, Diversis Episcopis Senator PPO., Variae XI, 3, 2 (ŹMT 79, s. 414).

${ }^{33}$ Cassiodorus, Diversis Episcopis Senator PPO., Variae VI, 3, 6 (ŹMT 79, s. 415).

${ }^{34}$ Cassiodorus, Ambrosio V.I. agendi vices Senator PPO., Variae XI, 4, 1 (ŹMT 79, s. 416).

${ }^{35}$ Cassiodorus, Ambrosio V.I. agendi vices Senator PPO., Variae XI, 4, 3 (ŹMT 79, s. 416).

${ }^{36}$ Cassiodorus, Iohanni Cancellario Senator PPO., Variae XI, 6, 4 (ŹMT 79, s. 419).

${ }^{37}$ Cassiodorus, Iohanni Cancellario Senator PPO., Variae XI, 6, 6 (ŹMT 79, s. 419). 
Kochajcie sprawiedliwość, która niech was uczyni godnymi miłości i dzięki swemu udziałowi przyniesie chwalebną korzyść. Wiedzcie, że wasze obowiązki towarzyszą wam niby świadkowie waszych działań. Dlatego jak wielką jest rzeczą czynić na oczach tak znacznych to, co mogą głosić usta wszystkich ${ }^{38}$.

Nie godziło się zatem, aby sędzia czynił coś, o co mógłby być oskarżany. Obowiązkiem urzędników była troska o dobre obyczaje, dobro poddanych, udzielanie dobrodziejstwa wynikającego z prawa oraz kierowanie się własnym sumieniem $^{39}$. W piśmie skierowanym do Ambrożego prefekt pretorium pisze o zapewnieniu materialnego dostatku mieszkańcom Rzymu. Przy tej okazji wyraża swój pogląd na temat sprawiedliwości społecznej:

Niech Bóg broni, abyśmy sycili się, kiedy ktokolwiek z tego miasta głoduje. Niedostatek obywateli (oby go nie znali!) jest naszą nędzą. Cóż więcej? Nie możemy być zadowoleni, jeśli nie słyszymy ich powszechnej radości. I dlatego z całą energią należy zebrać niezepsute rodzaje zboża, tak aby wypieczony z nich chleb nie odstraszał, lecz doskonale smakował. (...) Unikajcie występnych zysków, strońcie od niegodziwych korzyści. Cokolwiek złego tu się zamyśla, sprawia mi przykrość. Niech nikt nie uznaje za okazję do przekupstwa, jeżeli w tej sytuacji będzie starał się coś wziąćc ${ }^{40}$.

Kasjodor miał świadomość, że kierowanie wysokimi urzędami państwowymi związane jest $\mathrm{z}$ wielką odpowiedzialnością i potrzebą surowości w celu zaprowadzenia pokoju i porządku. W piśmie skierowanym do wszystkich sajonów, posiadających kompetencje wojskowe i cywilne, nasz autor wskazuje na egzekwowanie prawa i stosowanie $\operatorname{kar}^{41}$ :

W państwie jednak występuje tak wielkie zróżnicowanie, że nikt nie może bronić praw, o ile pewnymi sprawami nie pokieruje strach. Chorzy nie mają jednej przyczyny wyzdrowienia; jeden dochodzi do zdrowia dzięki pożywieniu, inny szczupleje dzięki dobrodziejstwu wstrzemięźliwości; ten poszukuje delikatnych kąpieli, tamten żelaza na rany - różne rodzaje dolegliwości wymagają różnego lekarstwa. $\mathrm{W}$ ten sposób ten, kto chce przewodzić ludziom, nie może być obdarzony jedną zdolnością. Dzikich trzeba kiełznać surowością, łagodnych życzliwie napominać; podstępnych traktować ostrożnie, prostych spokojnie. Dlatego też wszędzie, jak

${ }^{38}$ Cassiodorus, Iudicibus provinciarum Senator PPO., Variae XI, 9, 2-3 (ŹMT 79, s. 424).

${ }^{39}$ Cassiodorus, Iudicibus provinciarum Senator PPO., Variae XI, 9, 4 (ŹMT 79, s. 425).

${ }^{40}$ Cassiodorus, Ambrosio V.I. agenti vices Senator PPO., Variae XI, 5, 2-3 (ŹMT 79, s. 417).

${ }^{41}$ Zob. Apparatus criticus (ŹMT 79, s. 32). 
się okazuje, niezbędna jest roztropność, ponieważ do wszystkich rzeczy należy stosować odpowiednie środki ${ }^{42}$.

W piśmie do dostojnego Waleriana Kasjodor pisze o obowiązkach sędziów, podkreślając, że ich siłą jest prawo. Dlatego powinni oni z całą surowością ścigać tych, którzy go nie przestrzegają i dopuszczają się przestępstw:

Siłą sędziów jest prawo. Niech ławy sądowe nie przestaną grzmieć przeciwko złym obyczajom; niech łotr boi się wyroku, którego zawsze się obawiał. Niech cudzołożnik drży przed sędzią, fałszerz wzdryga się na głos woźnego sądowego; niech złodziej nie naśmiewa się z sądu, ponieważ wolność cieszy wówczas, gdy takie rzeczy są powodem do radości. (...) Niech nikt nie uciska biedaka. Karćcie tych, którzy dopuszczają się napaści, ścigajcie prześladowców. Waszą sprawą jest wojna obywatelska. Doprowadźcie do powszechnego uspokojenia, jeśli okiełznacie hersztów zbrodni. Troszcz się o właściwe wyliczanie racji żywnościowych, aby nikt nie został podstępnie oszukany ${ }^{43}$.

W edykcie prefekta pretorium dla prowincji czytamy, że zwyczajem starożytnych było stanowienie nowych praw. W obecnym czasie - jak podkreśla nasz autor - wystarczy świadomość konieczności zachowania praw przodków. Każdy, kto dobrze postępuje, ma obawiać się czegokolwiek, co mogłoby mu przysparzać lęku. Dlatego należy kochać życie w spokoju, bez winy i niedozwolonych zuchwałości, ponieważ respektowanie prawa prowadzi do pokoju i chroni przed gwałtem i kłótniami ${ }^{44}$.

Jakim przełożonym był dla swoich podwładnych Kasjodor? Z pewnością wymagającym i sprawiedliwym, co można wywnioskować na podstawie jego pism. W edykcie skierowanym dla prowincji nasz autor sam o sobie pisze w następujący sposób:

Przyjmijcie zatem jako gwarancję mojego nastawienia zwierciadło serca, obraz woli, abym ze względu na wartość mojego charakteru został uznany przez tych, którym nie jestem znany z oblicza. Zobaczcie mnie raczej w ten sposób, w który osobiście obecni są niedostępni. Nie doznajecie żadnej szkody wskutek mojej nieobecności jest korzystniejsze poznawać po jego usposobieniu niż po wyglądzie zewnętrznym ${ }^{45}$.

${ }^{42}$ Cassiodorus, Universis saionibus qui sunt cancellariis deputati Senator PPO., Variae XII, 3, 1 (ŹMT 79, s. 452).

${ }^{43}$ Cassiodorus, Valeriano V.S. Senator PPO., Variae XII, 5, 6 (ŹMT 79, s. 456).

${ }^{44}$ Cassiodorus, Edictum per provincias. Senator PPO., Variae XI, 8, 2 (ŹMT 79, s. 422).

${ }^{45}$ Cassiodorus, Edictum per provincias. Senator PPO., Variae XI, 8, 9 (ŹMT 79, s. 423-424). 


\section{Awans i gratyfikacja urzędników}

Kilkanaście pism naszego autora zostało poświęconych tematyce gratyfikacji i awansom zawodowym urzędników. $Z$ dokumentów wynika, że promocje pracowników biur miały zazwyczaj miejsce w uroczystość Bożego Narodzenia, ponieważ - jak pisze Kasjodor - w tym dniu Odkupienia znajdujemy życiowe remedium, które przed całą ludzkością otwiera nadzieję na zbawienie. Zatem człowiekowi zmęczonemu długotrwałym trudem należy podać „lekarstwo radości”, jakim jest ogłoszenie awansu każdego z urzędników zgodnie z porządkiem rangi i zachowaniem kolejności szczebli awansu ${ }^{46}$. Procedura awansu polegała na tym, że zwalniano ze stanowiska kogoś dobrze zasłużonego, dając kandydatom nadzieję na kolejne stanowiska. Odejście jednego urzędnika uruchamiało karuzelę stanowisk. W Variae znajdują się dokumenty odwołujące i powołujące następujących urzędników biura Kasjodora: adiutant, kornikulariusz ${ }^{47}$, naczelnik kancelarii, skriniariusz ${ }^{48}$, nadzorca akt prawnych, skriniariusz spraw wojskowych, zwierzchnik biura pism przychodzących, urzędnik szóstego stopnia w korporacji, prerogatywariusz ${ }^{49}$, sekretarz pism publicznych, regendariusz ${ }^{50}$, primiceriusz $^{51}$ urzędników przeznaczonych do służby na dworze oraz primiceriusz kurierów cesarskich ${ }^{52}$.

${ }^{46}$ Cassiodorus, Promotiones Oficii Praetoriani quae Natale Domini fiunt, Variae XII, 17, 1-2 (ŹMT 79, s. 432-433).

${ }^{47}$ Kornikulariusz - to urzędnik najwyższy rangą spośród pisarzy i stenografistów, którzy pracowali w kancelarii prefekta pretorium. Jego kadencja trwała rok, a po jej ukończeniu urzędnik opuszczał biuro prefekta i był zastępowany przez kolejnego w hierarchii kancelistę - zob.: O. J. Zimmermann, The Late Latin Vocabulary of the „Variae” of Cassiodorus, With Special Advertence of the Technical Terminology of Administration, Washington 1944, s. 217; Apparatus criticus (ŹMT 79, s. 433).

${ }^{48}$ Skriniariusz - to nazwa dla urzędnika kancelaryjnego, archiwariusza. Scrinarius actorum był odpowiedzialny za akta prawne w kancelarii prefekta pretorium - zob.: O. J. Zimmermann, dz. cyt., s. 247-249; Apparatus criticus (ŹMT 79, s. 434).

49 Prerogatywariusz - tytułem tym byli oznaczani urzędnicy, pochodzący z kancelarii prefekta, wybierani corocznie przez niego i podlegający bezpośrednio niemu - zob.: O. J. Zimmermann, dz. cyt., s. 239-240; Apparatus criticus (ŹMT 79, s. 436).

${ }^{50}$ Regendariusz - to urzędnik odpowiedzialny w biurze prefekta za sprawy związane z pocztą - zob.: O. J. Zimmermann, dz. cyt., s. 245; Apparatus criticus (ŹMT 79, s. 436).

${ }^{51}$ Primiceriusz - zwierzchnik wydzielonego biura w administracji cesarskiej i urzędnik wyższej rangi - zob. W. Ensslin, Primicerius, w: Realencyclopädie der classischen Altertumwissenschaft, Supplementband VIII, Stuttgart 1956, kol. 614-624.

${ }_{52}$ Zob.: Cassiodorus, De corniculario qui egreditur, Variae XI, 18 (ŹMT 79, s. 433); De corniculario qui accedit, Variae XI, 19 (ŹMT 79, s. 433-434); De primiscrinio qui egreditur, Variae XI, 20 (ŹMT 79, s. 434); De primiscrino qui accedit, Variae XI, 21 (ŹMT 79, s. 434); De scrinario actorum, Variae XI, 22 (ŹMT 79, s. 434); De cura epistularum, Variae XI, 23 (ŹMT 79, s. 434-444); De scrinario curae militaris, Variae XI, 24 (ŹMT 79, s. 435); De primicerio exceptorum, Variae XI, 25 (ŹMT 79, s. 435); De praerogativario, Variae XI, 27 (ŹMT 79, s. 436); De commen- 
W piśmie uprawniającym do wynagrodzenia pewnego urzędnika, datowanym przed 24 grudnia 534 roku, Kalabryjczyk porównuje pracę urzędnika do woźnicy $\mathrm{w}$ wyścigu olimpijskim, który po trudach zawodów zbiera nagrody ${ }^{53}$. Jednocześnie zauważa, że służba publiczna, która związana jest $\mathrm{z}$ wieloma niedogodnościami, zasługuje na właściwą gratyfikację:

Dlaczego bowiem jeden z urzędników publicznych po wielu niepewnych trudach ma pozostawać w niepewności, skoro zasłużył częstą służbą poza domem na wyróżnienie, przewyższając innych wypełnieniem obowiązków? Stale bowiem przestrzegał nakazów władcy i aby wyróżnić poszanowanie biura pretorskiego, przystąpił do takiej służby zaraz po nominacji. Opóźnienia wobec takich ludzi są przestępstwem, gdyż po zwycięstwie nikogo się nie odsuwa ${ }^{54}$.

Piastowanie urzędów związane było także z przydzielaniem osobom zatrudnionym rodzaju pomocy żywnościowej określanej jako delegatio ${ }^{55}$. Według Kasjodora zamożność tego, komu przedłuża się kadencję urzędniczą, powinna wzrastać stosownie do zajmowanego stanowiska. Dlatego w przypadku przysługujących urzędnikom racji żywnościowych należy unikać korupcyjnych opóźnień i szkodliwej pychy ${ }^{56}$. Zdaniem naszego autora służba publiczna powinna być kadencyjna i zapewniać także godne środki u schyłku życia. Dlatego - jak pisze Kasjodor - w niepewnym życiu pewną rzeczą winna być służba publiczna $^{57}$. W piśmie do prześwietnego Lucyna Kasjodor pisze, że słuszne wynagrodzenie za swój trud winni otrzymać ci, którzy pracują na rzecz państwa:

Dobrze rozporządziła starożytność, że słuszne wynagrodzenie za swój trud winni otrzymywać ci, którzy pracują na rzecz pożytku publicznego, aby nie pominięto tego, kogo należało pochwalić za wzorową służbę. (...) Niemal wszystko, co dzieje się w państwie, realizowane jest dzięki ich wysiłkom, a - co jest najtrudniejszym rodzajem służby - związane z nią obowiązki muszą być wypełniane w ten sposób, by urzędnik nie przekroczył swych uprawnieńn ${ }^{58}$.

tariense, Variae XI, 28 (ŹMT 79, s. 436); De regendario, Variae XI, 29 (ŹMT 79, s. 436); De primicerio deputatorum et de primicerio augustialum, Variae XI, 30 (ŹMT 79, s. 437); De primicerio singulariorum qui egreditur, Variae XI, 31 (ŹMT 79, s. 437); De primicerio singulariorum qui accedit, Variae XI, 32 (ŹMT 79, s. 437).

${ }_{53}$ Cassiodorus, Delegatoria, Variae XI, 35 (ŹMT 79, s. 439).

${ }^{54}$ Cassiodorus, Delegatoria, Variae XII, 35, 1-2 (ŹMT 79, s. 439).

${ }_{55}$ Cassiodorus, De concedendis delegatoriis, Variae XX, 33 (ŹMT 79, s. 438).

${ }_{56}$ Cassiodorus, Delegatoria, Variae XII, 35, 3 (ŹMT 79, s. 439).

${ }^{57}$ Cassiodorus, Anatolico Cancelario provinciae samni Senator PPO., Variae XII, 36, 1 (ŹMT 79, s. 439-440).

${ }^{58}$ Cassiodorus, Lucino V.C. Cancellario campaniae Senator PPO., Variae XII, 37, 1 (ŹMT 79, s. 441). 
Powołując się na przykłady służby urzędników podatkowych Kasjodor zwraca uwagę na znaczenie wiedzy praktycznej urzędników, którą otrzymuje się od wymagających nauczycieli i gorliwych pedagogów. Dzięki nim pracownik zdobywa doświadczenie zawodowe, które z kolei zasługuje na zaszczytne wynagrodzenie umotywowane zasługami wobec państwa i społeczeństwa ${ }^{59}$.

\section{Walka z korupcją}

W pismach Kasjodora pojawia się często tematyka nadużyć urzędników o charakterze korupcyjnym i zagadnienie troski o wysoki poziom moralności osób pracujących w służbie państwowej. Jako prefekt pretorium zajmował się on także kwestiami spornymi dotyczącymi płacenia podatków i ustalania cen żywności. W piśmie skierowanym do wszystkich zarządców w prowincjach nasz autor podejmuje kwestię płacenia podatków, dzięki którym - jak pisze - jest się lojalnym poddanym. Zachęca on zarządców prowincji, aby wraz z personelem swojego biura napominali właścicieli ziemskich do płacenia podatku gruntowego rzetelnie i w ustalonych terminach:

Dla właściciela miła jest jedynie ta posiadłość, na której nie lęka się pojawienia egzekutora. Słusznie więc zaświadczenie o zapłaceniu podatków nazywa się „zabezpieczeniem”, które chroni nie tylko myśli, lecz i majątek ${ }^{60}$.

Kalabryjczyk potępia praktykę odraczania podatków, przekupstwo i łapówkarstwo ${ }^{61}$. Podkreśla on znaczenie posłuszeństwa wobec przełożonego, które polega na wypełnianiu jego poleceń oraz na unikaniu niedbalstwa. Przestrzega on przed „szpetnymi zyskami” i zachłannością i podkreśla, że najwłaściwszą cechą osoby pełniącej służbę publiczną jest czyste sumienie i uczciwe postępowanie, które nie pozostaje bez nagrody i pochwały ${ }^{62}$.

Prefekt pretorium zdecydowanie przestrzega przed kupczeniem i zachęca, aby ręce poddanych i urzędników były czyste. Zwraca on uwagę na fakt, że jeśli od podwładnych wymaga się uczciwości i dobrego przykładu, to tym bardziej winni ją okazywać urzędnicy. Priorytetem postępowania urzędników jest

${ }^{59}$ Cassiodorus, Lucino V.C. Cancellario campaniae Senator PPO., Variae XII, 37, 2-4 (ŹMT 79, s. 441-442).

${ }^{60}$ Cassiodorus, Universis Iudicibus provinciarum Senator PPO., Variae XI, 7, 1 (ŹMT 70, s. 420).

${ }^{61}$ Cassiodorus, Universis Iudicibus provinciarum Senator PPO., Variae XI, 7, 1-3 (ŹMT 79, s. 420$)$.

${ }^{62}$ Cassiodorus, Universis Iudicibus provinciarum Senator PPO., Variae XI, 7, 5-6 (ŹMT 79, s. 421). 
bowiem korzyść publiczna, a nie ich prywatne interesy, dlatego ich wypowiedzi powinny być poparte przykładem i być dalekie od przejawów jakiejkolwiek korupcji ${ }^{63}$. Kasjodor troszczył się również o dobro publiczne i sprawiedliwy podział dóbr. Przykładem tego może być edykt dotyczący utrzymania cen w Rawennie:

Cena produktów żywnościowych winna być racjonalna, tak aby ani nie było tanio w okresie drożyzny, ani drożyzny w okresie taniości, lecz by dzięki dokładnemu i zgodnemu z wymogami sprawiedliwości rozważeniu tej sprawy unikać zarówno szemrania kupujących, jak i utyskiwań sprzedających. Dlatego po przemyśleniu tego wszystkiego ustaliliśmy w niżej załączonym dokumencie ceny różnych produktów, aby dzięki usunięciu wszelkiej dwuznaczności można było nad nimi zapanować. Jeżeli zaś jakiś sprzedawca nie będzie przestrzegał cen wymienionych w niniejszym edykcie, za każde wykroczenie będzie podlegał grzywnie w wysokości sześciu solidów i może podlegać karze chłosty, aby zarówno odstraszył go lęk przed karą, jak i dotknęła swą dolegliwością wspomniana kara ${ }^{64}$.

W edykcie dotyczącym cen przy via Flaminia Kasjodor pisze na temat sprawiedliwych cen dla niepracujących i pracujących mieszkańców miast. Potępia on zachłanność tych, którzy goszcząc podróżujących, pobierają od nich zbyt wysokie obciążenia i nazywa bandytą tego, kto kierując się niegodziwym zyskiem i chęcią wzbogacenia się, samowolnie ustala ceny. Większą korzyść przynosi bowiem umiarkowanie niż zachłanne gonienie za zyskiem ${ }^{65}$. W piśmie skierowanym do mieszkańców Ligurii nadawca odnosi się do skargi dotyczącej obciążenia ich niesprawiedliwymi wagami i miarami. Kasjodor pisze, że urzędnicy, poborcy i komornicy, którzy zostali oskarżeni o wyrządzenie tej niesprawiedliwości, będą wezwani do biura w celu wyjaśnienia tych spraw ${ }^{66}$.

Jednymi z najważniejszych urzędników pełniących służbę państwową byli sędziowie. Kalabryjczyk wskazuje na ich szczególną odpowiedzialność za sprawy publiczne i pisze, że określenie „sędzia” odnosi się do sprawiedliwości ${ }^{67}$. W piśmie skierowanym do różnych kanclerzy w poszczególnych prowincjach przestrzega przed postępowaniem ze złą intencją. Nasz autor podkreśla, że prawo obowiązuje w równym stopniu wszystkich oraz przedstawia cechy sędziego: mądrość, sprawiedliwość i nienaganna opinia potwierdzona dobrymi czynami. Sędziom powinno być obce rozpowszechnianie obmowy, gniew i chci-

${ }^{63}$ Cassiodorus, Edictum per provincias. Senator PPO., Variae XI, 8, 5-6 (ŹMT 79, s. 423).

${ }^{64}$ Cassiodorus, Edictum de pretiis custodiensis Ravenna, Variae XI, 10, 1-2 (ŹMT 79, s. 426$-427)$.

${ }^{65}$ Cassiodorus, Edictum pretorium per Flaminiam, Variae XI, 12, 1-3 (ŹMT 79, s. 427).

${ }^{66}$ Cassiodorus, Liguribus Senator PPO., Variae XI, 16, 1-4 (ŹMT 79, s. 431).

${ }^{67}$ Cassiodorus, Indulgentia, Variae XI, 40, 1 (ŹMT 79, s. 445). 
wość, która nazywana jest „królową zuchwałych występków” i prowadzi do zbrodni ${ }^{68}$. Kalabryjczyk uważa, że urząd publiczny sędzia winien sprawować z moralną powściągliwością, ponieważ więcej zdziała ten, który odwołuje się w swojej argumentacji do rozumu, niż ten, który posługuje się strachem ${ }^{69}$.

W piśmie skierowanym do wszystkich przełożonych w prowincjach Kasjodor pisze, że on sam nie splamił się sprzedajnością oraz że nikt w kwestiach publicznych i prywatnych nie doznał z jego powodu uszczerbku. Przy tej okazji nasz autor zachęca do przestrzegania prawa:

Niech nikogo nie odrzuca przestrzeganie prawa: ono wychwala wszystkich, których wynosi dzięki temu, że w nim uczestniczą: mniejszym czyni się samemu ten, kto od niego odchodzi. Dlaczego mielibyśmy dążyć do zyskiwania darów? Żadnej chwały nie zyskuje ten, kto nazywa się bogatym, natomiast wszelka chwała zdobi tego, kto nazywa się sprawiedliwym ${ }^{70}$.

Sędziom nie przystoi zatem nic pożądliwego i występnego, ich postępowanie powinno być prawe i przejrzyste, ponieważ tylko w taki sposób można naprawić błędy innych, jeśli samemu jest się człowiekiem prawym i sprawiedliwym. Ponadto sędzia winien kierować się dobrem pożytku publicznego i wykonywać polecenia przełożonych ${ }^{71}$.

W piśmie do urzędników prefektury wszystkich stopni Kalabryjczyk przestrzega urzędników państwowych przed zachłannością i bezczelną zuchwałością. Krytykuje branie łapówek i niegodziwe oszustwa, oznajmiając, że ci, którzy dopuszczają się takich przestępstw, będą ścigani i poniosą karę. Pracownicy administracji publicznej mają być uczciwi w działaniu i służyć niezmiennie pożytkowi publicznemu ${ }^{72}$. W piśmie do prześwietnego Piotra szafarza rozdawnictw publicznych Kasjodor ostrzega przed nieuczciwością:

Człowiek, który nadzoruje dobrodziejstwa władców, winien być nieposzlakowanej uczciwości, aby wskutek jakiegoś skalania pożądliwością nie wyschło to, co wypływa z tak wielkiej łaskawości. Pewne rozdawnictwa bowiem ulegają zmianie pod działaniem łupieżczej ręki i podobnie jak czystość źródła ulega zepsuciu

${ }^{68}$ Cassiodorus, Universis Iudicibus provinciarum Senator PPO., Variae XII, 1, 5 (ŹMT 79, s. 450).

69 Tamże.

${ }^{70}$ Cassiodorus, Universis Iudicibus provinciarum Senator PPO., Variae XII, 2 , 3 (ŹMT 79, s. 451).

${ }^{71}$ Cassiodorus, Universis Iudicibus provinciarum Senator PPO., Variae XII, 2, 5-6 (ŹMT 79, s. 451-452).

${ }^{72}$ Cassiodorus, Universis praefecturae titulos administrantibus Senator PPO., Variae XII, 6, 1-3 (ŹMT 79, s. 457-458). 
pod wpływem mułu, tak też napływ dóbr ze strony króla ulega zmianie na skutek działania chciwych szafarzy ${ }^{73}$.

Postępowanie Kasjodora cechowało się wyczuleniem na sprawy pożytku publicznego oraz troską o dobro obywateli. Przykładem tego może być edykt, który potępia nieuczciwość poborców podatkowych ograbiających majątek kościelny. Zdaniem naszego autora taka kradzież nie może pozostać bez kary Bożej i ludzkiej. Dlatego też powyższy edykt ustanawia prawo, że każdy, kto dopuściłby się przestępstwa oszustwa, winien być pozbawiony urzędu i utracić dochód ze swego majątku ${ }^{74}$.

Urzędem państwowym, który według Kalabryjczyka narażony był szczególnie na propozycje o charakterze korupcyjnym było stanowisko pisarza, ponieważ dysponował on ważnymi dokumentami: „Jego szafa na dokumenty jest fortuną wszystkich i słusznie nazywa się ją ucieczką wszystkich, gdzie wszyscy znajdują bezpieczeństwo"75.

Pisarz według Kasjodora jest strażnikiem wielkiej sprawy, ponieważ wchodzi on w obowiązki ojcowskie, gdy autentycznie strzeże prawdy. Znaczenie tego urzędu uwidaczniało się również w tym, że wszyscy sędziowie mogli prowadzić sprawy dzięki jego staranności i dbałości o dokumenty, które stanowiły podstawę do prowadzenia procesów i wyrokowania. W piśmie do pisarza Rawenny Deusdedita prefekt pretorium przestrzega przed nieuczciwością:

Dlatego nie żyw korupcyjnych zamiarów. Molem dla dokumentów jest szkodliwa łapówka ze strony tego, kto dopuszcza się przekupstwa, ponieważ tacy ludzie usiłują zniszczyć to, o czym wiedzą, że stoi na ich drodze. Niech żywi Cię przystojne głoszenie prawdy; niech twoim uprawnieniem będzie uczciwość. Daj tym, którzy o to proszą, sporządzone niegdyś dokumenty. Bądź przekazicielem, nie zaś twórcą dawnych faktów ${ }^{76}$.

Kasjodor przestrzega adresata, aby nikt go nie pozyskał niegodziwym podstępem i przekupstwem, zachęcając do umiłowania sprawiedliwości. Jedynie prawe postępowanie oraz transparentność w kwestii spraw publicznych może spotkać się z wdzięcznością, jak również z uszanowaniem ${ }^{77}$.

${ }^{73}$ Cassiodorus, Petro V.C. erogatorii Opsoniorum Senator PPO., Variae XII, 11, 1 (ŹMT 79, s. 462).

${ }^{74}$ Cassiodorus, Edictum, Variae XII, 13, 1-3, 9 (ŹMT 79, s. 465).

${ }^{75}$ Cassiodorus, Deusdedit Scribae Ravennati Senator PPO., Variae XII, 21, 2 (ŹMT 79, s. 475).

${ }^{76}$ Cassiodorus, Deusdedit Scribae Ravennati Senator PPO., Variae XII, 21, 4 (ŹMT 79, s. 475).

77 Cassiodorus, Deusdedit Scribae Ravennati Senator PPO., Variae XII, 21, 5 (ŹMT 79, s. 475 ). 


\section{Zakończenie}

Przeprowadzone badania ukazały działalność Kasjodora na jednym z najwyższych stanowisk państwowych, jakim był urząd prefekta pretorium w okresie panowania Ostrogotów. Podsumowując powyższe opracowanie, należy stwierdzić, że z pism Kasjodora wyłania się postać człowieka o dużej kulturze słowa, wielkim szacunku dla rzymskiej tradycji, lojalnego i sprawiedliwego, wymagającego od siebie i innych, a nade wszystko wolnego od przekupstwa i korupcji. $\mathrm{Na}$ podstawie pism urzędowych Kasjodora, znajdujących się w XI i XII księdze Variae, można przedstawić poglądy tego autora na temat sprawowania urzędów państwowych wszystkich szczebli władzy. Na pierwszym miejscu Kasjodor umieszcza posłuszeństwo wobec władzy oraz zachowywanie prawa. Kalabryjczyk podkreśla równość wszystkich wobec prawa i wiele uwagi poświęca sprawiedliwości społecznej, podkreślając kolejne cechy urzędnika, jakimi są kierowanie się dobrem rzeczpospolitej i każdego jej obywatela. Pracownicy biur powinni charakteryzować się właściwymi kwalifikacjami, doświadczeniem i pracowitością, winni być wyszkoleni i skuteczni, mając na uwadze przede wszystkim służbę publiczną dla pożytku państwa. Zaangażowanie i długoletnia praca urzędników nie może pozostać bez uznania i należnej gratyfikacji, czemu służyły awanse i delegacje urzędników. Nasz autor uważa, że służba publiczna winna być właściwie wynagradzana, ponieważ urzędnik pełni służebną rolę wobec społeczeństwa i państwa. Pracownikowi biura po długoletniej służbie przysługiwało zagwarantowanie godnych środków życia na starość. Pisząc o zasadach piastowania urzędów państwowych, nie sposób nie wspomnieć o jego walce z korupcją i nadużyciami. Kasjodor stanowczo i zdecydowanie występuje przeciwko jakimkolwiek formom nieuczciwości i niesprawiedliwości, potępiając: kradzieże, łapówkarstwo, przekupstwo, sprzedajność i łamanie prawa. Na zakończenie należy zauważyć, że tematyka powyższego opracowania jest wciąż aktualna - i pomimo odległości czasowej oraz odmiennych realiów historycznych - zasady sprawowania urzędów państwowych, o których pisze Kasjodor, nie straciły na aktualności i stanowią wysokie standardy osoby piastującej urzędy różnych szczebli.

\section{Streszczenie}

W powyższym artykule podjęto tematykę zasad sprawowania urzędów państwowych na podstawie ważnego dla historiografii i kultury europejskiej dzieła Variae autorstwa Kasjodora. Pismo to składa się z dwunastu ksiąg i zawiera dokumenty urzędowe oraz pisma królewskie z lat 489-538. W oparciu o analizę tekstu źródłowego, szczególnie XI i XII księgi wyżej wspomnianego dzieła, przeanalizowano dokumenty, które Kasjodor napisał w czasie pełnienia przez niego jednego z najważniejszych urzędów w królestwie Ostrogotów - prefekta pretorium. W opracowa- 
niu, które składa się z czterech części, wskazano na najważniejsze zasady piastowania urzędów. W pierwszym punkcie przedstawiono osobę i działalność samego Kasjodora jako prefekta pretorium, wskazując na jego wysokie kwalifikacje, prawość oraz odpowiedzialność za państwo. W drugim punkcie ukazano dwie ważne zasady, którymi powinni charakteryzować się urzędnicy: posłuszeństwo i lojalność wobec władzy oraz zachowywanie prawa. W kolejnym punkcie zaprezentowano tematykę awansów i gratyfikacji urzędników, które wynikały z pełnienia służby publicznej. Ostatni punkt został poświęcony walce z korupcją i nadużyciami, w szczególności z przekupstwem, kradzieżami, łapówkarstwem i łamaniem prawa. Tematyka powyższego opracowania jest wciąż aktualna. Zasady sprawowania urzędów, o których pisze Kasjodor, nadal stanowią wysokie standardy osoby piastującej urzędy państwowe różnych szczebli.

\section{Słowa kluczowe}

Kasjodor, prefekt pretorium, Variae, urząd państwowy, królestwo Ostrogotów

\section{Cassiodorus' views on the principles of ruling in various high offices on the basis of 11th and 12th Books of Variae}

\section{Summary}

In the article the author presents the principles of ruling in various high offices on the basis of Variae by Cassiodorus - the work of great importance to historiography and the European culture. The work consists of twelve books - official documents and the royal ones from the years 489-538. On the basis of the source text, especially books 11th and 12th of Variae, the most important documents are analysed. These documents were written at the time of serving in the administration of the king of Ostrogoths, when Cassiodorus was the praetorian prefect. The paper is divided into four parts. The first point is devoted to the description and the scope of activity of the praetorian prefect, pointing to his high qualifications, integrity and responsibility for the country. In the second point the author presents the two rules that should be followed by officials: being obedient and loyal to the authority, as well as preserving the law. The next point is devoted to preferment and the payment officials received, which resulted from working in public service. The last point is devoted to combating corruption and malpractice, especially bribery, theft and breaking the law. The issues raised in this paper are still current and the principles of ruling in various high offices proposed by Cassiodorus are still of high standards for the person who holds an office in the government.

\section{Keywords}

Cassiodorus, praetorian prefect, Variae, governmental office, the Ostrogothic Kingdom 


\section{Bibliografia}

Bürsgens W., Einleitung, w: Cassiodorus, Institutiones divinarum et saecularium litterarum, ed. W. Bürsgens (FC 39/1-2), Freiburg im Breisgau 2003, s. 9-88.

Cappuyns M. D., Cassiodore, DHGE XI, Paris 1949, s. 1349-1408.

Cassiodorus, Anecdoton Holderi. Ein Beitrag zur Geschichte Roms in ostgotischer Zeit, ed. H. Usener, Hildesheim-New York 1969.

Cassiodorus, De anima. Liber de anima, ed. J. W. Halporn (CCL 96), Turnhout 1973, s. 535-575.

Cassiodorus, De orthographia (PL 70, 1239-1270).

Cassiodorus, Institutiones divinarum et saecularium litterarum, ed. W. Bürsgens (FC 39/1-2), Freiburg im Breisgau 2003.

Cassiodorus Senator, Variae, MGH AA XII, T. Mommsen, ed. Berolini 1894; Variarum libri XI, A. J. Fridh, ed. CCL, Turnholti 1973; Kasjodor Senator, Variae (I-XII), tłum. A. Kołtunowska, Przedmowa, Księgi I-V.IX, R. Sawa - Księgi VI-VIII.X-XII, rewizja przekładu i opracowanie M. Ożóg, H. Pietras, Synody i Kolekcje Praw, t. XI (ŹMT 79), Kraków 2017.

Ensslin W., Primicerius, w: Realencyclopädie der classischen Altertumwissenschaft, Supplementband VIII, Stuttgart 1956, kol. 614-624.

Fridh A. J., Cassiodor, TRE VII, Berlin-New York 1981, s. 657-663.

Górski G., Historia administracji, Kraków 2011.

Jakubowski I., Stanowisko pretora $w$ „,Kodeksie Teodozjańskim” o „,Nowelach Postteodozjańskich”, „Acta” UL 32(1978), s. 35-45.

Kakridi Ch., Cassiodors Variae. Literatur und Politik im ostgotischen Italien, LeipzigMünchen 2005.

Kieling M., Rola Pisma Świętego $i$,, artes liberales” w ksztattowaniu nauk teologicznych i świeckich wedtug Kasjodora, Poznań 2011.

Mommsen T., Ostgotische Studien: Historische Schriften 3, Berlin-Dublin-Zürich 1965.

O’Donnell J. J., Cassiodorus, Berkeley-Los Angeles-London 1979.

Ożóg M., ,Inter duas potestates”. Polityka religijna Teoderyka Wielkiego, Kraków 2012.

Ożóg M., Rozporzadzenia prawne Teoderyka Wielkiego wkwestiach religijnych w ,Variae” Kasjodora, w: Rzymianie i barbarzyńcy. Religia - polityka - kultura. Materiaty V kongresu mediewistów polskich, t. 6, Rzeszów 2019, s. 169-188.

Ruciński S., „Praefectus Urbi”. Strażnik porzadku publicznego w Rzymie wokresie wczesnego Cesarstwa, Poznań 2012.

Skibiński T., „, Gothorum romanorumque consensus”. Jedność Gotów i Rzymian w dziatalności politycznej Amalasunty, „Vox Patrum”36(2016), t. 66, s. 235-249.

Zimmermann O. J., The Late Latin Vocabulary of the „Variae” of Cassiodorus, With Special Advertence of the Technical Terminology of Administration, Washington 1944. 